\title{
Research of the calorific value of dried alcohol distillery stillage
}

\author{
Oleksandr Ivashchuk ${ }^{1}$, Volodymyr Atamanyuk $^{1}$, Roman Chyzhovych $^{1}$, \\ Tetiana Kuzminchuk ${ }^{1}$, Roman Zherebetskyi ${ }^{2}$, Sofiia Kiiaieva ${ }^{1}$ \\ 1.Department of Chemical Engineering, Lviv Polytechnic National University, \\ UKRAINE, Lviv, 12 Bandery str., E-mail: oleksandr.s.ivashchuk@lpnu.ua \\ 2.Department of Organic Products Technology, Lviv Polytechnic National University, \\ UKRAINE, Lviv, 12 Bandery str.
}

\section{Abstract - The calorific value of dried corn alcohol distillery stillage was determined. The obtained data have shown a prospect for using distillery stillage as solid fuel.}

Keywords - alcohol distillery stillage, secondary raw materials, calorific value, solid fuel briquettes.

\section{Introduction}

The main by-product in the production of ethyl alcohol is alcohol distillery stillage, which is formed during the fermentation of food raw materials. Depending on the technology, about 1015 liters of stillage are formed per 1 liter of ethanol [1,2]. The dry matter content in the product is only up to $10 \%$ - and it leads to quick deterioration. Excessive humidity complicates subsequent use of alcohol distillery stillage and limits the area of its application.

Given the above, alcohol distillery stillage can be determined as a waste product, reprocessing or utilization of which is an important industrial task - because in Ukraine there are more than 80 distilleries, which produce about 4 million $\mathrm{m}^{3}$ of molasses stillage and 3.6-3.8 mln $\mathrm{m}^{3}$ of grain distillery stillage [3].

Alcohol distillery stillage is valuable for its chemical composition. The main components are sugars, glycerin, cellulose, starch, hemicellulose. There are also proteins, amino acids, vitamins, micro- and macronutrients, and carbohydrates [4]. Given this, the dry distillery stillage is ahead of most feed products, so its using in animal husbandry is the most rational. Alcohol distillery stillage can also be used as a plasticizer for concrete mixtures [4, 5], for the biogas obtaining [6]. Need to be noted, all these ways require previous drying of the product as usually.

A promising method of using of secondary raw materials with natural fibers is the production of solid fuel briquettes. Fuel pellets are an environmentally friendly source of energy used in municipal energy for heating residential buildings and technical premises. The energy required to produce pellets is about $10 \%$ higher than the energy content in the pellets themselves, which is used for drying raw materials, and to produce pellets from dry raw materials consumes only 1-2\% of the energy contained in them [7].

\section{Experimental}

The object of research was alcohol corn distillery stillage after the centrifugation process, obtained on the production line of SE «Vuzlove distillery» (Vuzlove, Lviv region, Ukraine) and dried by the filtration drying. The obtained material was analyzed to determine the residual moisture after filtration drying according to the method described in State Standard of Ukraine DSTU EN 14774-2: 2013. Solid biofuels. Determination of moisture content [8]. Determination of calorific value was done according to the requirements of State Standard of Ukraine DSTU EN 14918: 2016. Solid biofuels. Method for determining the calorific value [9].

\section{Results and discussion}

The dried sample of the corn distillery stillage was left for several days in room conditions, after that it was studied to determine the residual humidity according to the method from [8]. The 
research results showed an average humidity of $3.14 \pm 0.06 \%$ wt., which fully satisfies the industrial needs to increase the shelf life of the alcoholic distillery stillage and the possibility of its long-term storage and transportation.

The calorific value of the dried distillery stillage was experimentally determined according to [9]. The obtained value of the calorific value of alcoholic corn distillery stillage was $19545 \mathrm{~kJ} / \mathrm{kg}$ or $4672 \mathrm{kcal} / \mathrm{kg}$, and it is slightly higher than the calorific value of miscanthus and energy willow (Table 1), that are widely used for the solid fuel briquettes production [7, 10].

Table 1

The calorific value of dried distillery stillage and widely used plants for solid fuel production

\begin{tabular}{|l|c|c|c|}
\hline & $\begin{array}{c}\text { Dried corn distillery } \\
\text { stillage }\end{array}$ & Energy willow & Miscanthus \\
\hline Calorific value, $\mathrm{kJ} / \mathrm{kg}$ & 19545 & $\approx 17600$ & $\approx 17500$ \\
\hline
\end{tabular}

Additionally, the obtained value satisfies the requirements of European standards for pellets among countries such as Germany, Austria, Sweden [7].

\section{Conclusions}

Thus, the measurements of calorific value showed the prospects for the use of dried alcoholic corn distillery stillage as a solid fuel briquette, that requires subsequent research.

\section{References}

[1] Beltran, F. J. et al. (2001). Treatment of high strength distillery wastewater (cherry stillage) by integrated aerobic biological oxidation and ozonation. Biotechnology Progress, 17(3), 462-467.

[2] Nataraj, S. K., Hosamani, K. M., \& Aminabhavi, T. M. (2006). Distillery wastewater treatment by the membrane-based nano-filtration and reverse osmosis processes, Water Research, 40(12), 2349-2356.

[3] Mazur, A.H., Tsikhanovska, V.M. \& Hontaruk, Ya.V. (2013). Perspektyvy vyrobnyctva biogazu na spyrtovykh zavodax Vinnyckoyi oblasti. Naukovi praci Institutu bioenergetichnih kul'tur i cukrovykh burjakiv: zb. nauk. prac, 19, 245-249.

[4] Hizhnjak, M.I. \& Cion', N.I. (2010). Spirtova barda yak cìnna kormova dobavka j organìchne dobrivo u sil'skomu gospodarstvì. Ribogospodars'ka nauka Ukrajiny, 2, 122-130.

[5] Obodovych, A. \& Sydorenko, V. (2010). Barda spirtovyh zavodov - cennyj othod dlia proizvodstva kormovyh drozhzhej i betona. Keramika: Nauka I Zhittja, 4(29), 15-19. doi: $10.26909 / \mathrm{csl} .4 .2015 .2$

[6] Golub, N.B. \& Potapova, M.V. (2018). Tehnologiya oderzhannya biogazu z pislyaspyrtovoyi bardy. Vidnovljuvana energetyka, 2, 70-77.

[7] Roik, M.V., Sinchenko, V.M., Fuchylo Ya.D. et al. (2015). Energetychna verba: tehnologiya vyroschuvannya ta vykorystannya. Vinnycya: Niland-LTD.

[8] DSTU EN 14774-2:2013 (2015). Tverde biopalivo. Viznachennja vmistu vologi. Kyiv: Minekonomrozvytku Ukrajiny.

[9] DSTU EN 14918:2016 (2016). Tverde biopalivo. Metod viznachennya teplotvornoyi zdatnosti. Kyiv: Minekonomrozvytku Ukrajiny.

[10] Khivrych, O.B., Kvak, V.M., Kas'kiv V.V., Mamajsur, V.V. \& Makarenko, A.S. (2011). Energetychni roslyny yak alternatyva tradycijnym vydam palyva. Agrobiologiya, 6, 153-156. 